Рекомендована д. мед. наук, профр. О. М. Олещук

УДК 615.453.4:001.891

DOI 10.11603/2312-0967.2016.3.6825

\title{
КОМПЛЕКСНІ ДОСЛІДЖЕННЯ ЕКВІВАЛЕНТНОСТI IN VITRO КАПСУЛ МЕЛЬДОНІЮ
}

\author{
( С. Ю. Вісич, О. В. Доровський, О. Г. Фетісова, Л. М. Андрюкова \\ Національний фрармацевтичний університет, Харків
}

\begin{abstract}
Резюме: в статті наведено результати комплексу досліджень за процедурою біовейвер щодо встановлення біоеквівалентності досліджуваних та рефрерентних лікарських засобів мельдонію в формі твердих капсул по 250 мг та 500 мг. За результатами вивчення розчинності і ступеня проникнення встановлено I клас за БСК для діючої речовини мельдоній. Визначено, що об'єкти дослідження належать до дуже швидко розчинних лікарських засобів у всіх рекомендованих середовищах розчинення. Подібність профрілів розчинення свідчить про еквівалентність досліджуваних та ресрерентних лікарських засобів мельдонію.
\end{abstract}

Ключеві слова: мельдоній, капсули, біофармацевтична система класифрікації, біовейвер, дослідження біоеквівалентності in vitro, розчинність, профрілі розчинення.

Вступ. На сьогодні в зв'язку з обмеженістю ресурсів на охорону здоров'я збільшується увага до використання в медичній практиці генеричних лікарських засобів (ЛЗ) різних фрармако-терапевтичних груп, серед яких особливу увагу привертають антиішемічні препарати, оскільки лікування серцево-судинних захворювань уже досить тривалий час займає одне 3 провідних місць в сучасній медицині. Для збільшення насиченості фрармацевтичного ринку і задоволення потреби пацієнтів в ЛЗ цієї групи необхідне створення якісних, безпечних та ефективних генеричних препаратів вітчизняного виробництва, які за ціновою складовою значно дешевші від інноваційних препаратів. До ЛЗ цієї фрармако-терапевтичної групи належить лікарська речовина мельдоній, яка завдяки своїм властивостям в умовах підвищеного навантаження відновлює рівновагу між доставкою та потребою клітин у кисні, усуває накопичення токсичних продуктів обміну у клітинах, що захищає їх від ушкодження, проявляє тонізуючий ефрект. Мельдоній використовують у фрормі ін'єкційних розчинів і твердої лікарської форми для лікування різних порушень діяльності серцево-судинної системи, кровопостачання мозку, а також для підвищення орізичної і розумової працездатності [1].

Згідно 3 міжнародною регуляторною практикою реєстрація генеричного ЛЗ здійснюється за умови доведення його біоеквівалентності з редерентним препаратом, який насамперед повинен бути оригінальним (інноваційним) Лз із доведеними ефективністю, безпекою та якістю, що є основою для запобігання суттєвих фрармакологічних відмінностей при їх клінічному застосуванні. До ризиків, які можуть призвести до суттєвим фрармакологічним відмінностям, відносять: застосування ЛЗ для невідкладної допомоги; вузький спектр терапевтичної дії (межа есрективність/безпека), крутий нахил кривої доза-відклик; поліморфрізм діючої речовини.
Біоеквівалентність генеричного ЛЗ з референтним препаратом доводиться різними методами, одним 3 яких є біовейвер - спрощена процедура реєстрації генеричного ЛЗ на основі біофармацевтичної системи класифікації (БСК) та результатів порівняльних досліджень in vitro з використанням тесту «Розчинення». Цей підхід застосовується до лікарських препаратів (ЛП), які [2, 3]:

- знаходяться у твердих дозованих фрормах системної дії 3 негайним вивільненням для орального застосування;

- мають однакову лікарську фрорму;

- містять однакові лікарські речовини, які належать до I або III класу за БСК, тобто до речовин з високою розчинністю, та мають відому абсорбцію в людини;

- не мають вузького терапевтичного діапазону.

Порівняння досліджуваного та референтного препаратів in vitro враховує кількісний і якісний склад препаратів із точки зору діючих і допоміжних речовин, баланс ризиків з точки зору здоров'я людей і окремого пацієнта і базується на результатах трьох основних досліджень:

- визначення розчинності діючої речовини;

- визначення ступеня проникнення діючої речовини;

- визначення категорії ЛЗ і порівняння профрілів розчинення досліджуваного та рефрерентного препаратів.

Процедура біовейвер передбачає зменшення кількості досліджень біоеквівалентності in vivo та, якщо обґрунтовано еквівалентність Лз задовільними даними in vitro, дослідження біоеквівалентності in vivo можуть не проводитися [2]. Це також $є$ економічною складовою вартості ЛП.

Дана робота присвячена проведенню комплексних досліджень in vitro препарату Мілдралекс-Здоров'я, капсули по 250 мг та 500 мг, діючою речовиною якого $€$ мельдонію дигідрат, з метою визначення можливо-

ISSN 2312-0967. Pharmaceutical review. 2016. № 3 
Фармакокінетика і фармакодинаміка Pharmacokinetics and Pharmacodynamics

го застосування процедури біовейвера для державної реєстрації генеричного ЛЗ.

Методи дослідження. Об'єктами дослідження були: - субстанція мельдоній дигідрат виробництва «China Chem Co., Ltd» (Китай), що відповідає вимогам [4];

- Мілдралекс-Здоров'я, капсули по 250 мг та 500 мг дослідно-промислової серії виробництва ТОВ «ФК «Здоров'я», Україна;

- референтний препарат Мілдронат, капсули тверді по 250 мг і 500 мг виробництва Joint Stock Company «Grindeks», Латвія.

Всі дослідження проводили згідно із стандартизованою процедурою, що розроблена відповідно до рекомендацій [2] і затверджена на підприємстві.

Розчинність діючої речовини визначали у трьох буферних середовищах із значенням рН 1,2, pH 4,5 і pH 6,8 при температурі $(37 \pm 1)^{\circ} \mathrm{C}$ методом струшування у термостатичній колбі (shake-flask method) вищої разової дози активного фрармацевтичного інгредієнту (АФІ), яка складала 1 г $[1,5]$, до повного розчинення.

Вивчення розчинення проводили за допомогою приладу для проведення тесту на розчинення PHARMA TEST, PTWS 3CE (Німеччина) за наступними умовами: прилад із лопаттю, об'єм середовища розчинення - 900 мл, температура середовища розчинення - $(37 \pm 1)^{\circ} \mathrm{C}$, швидкість перемішування 50 об/хв, графрік відбору проб: 10, 15, 30 і 45 хв, буфрерні розчини $3 \mathrm{pH}$ 1,2, pH 4,5 і рН 6,8. Для кожного дослідження використовували по 12 одиниць ЛЗ для проведення статистичної оцінки.

Кількісне визначення мельдонію в усіх дослідженнях проведено за розробленою та валідованою методикою методом рідинної хроматограсрії, що наведена у методах контролю якості (МКЯ) на ЛЗ. Протягом усього експерименту контролювали значення $\mathrm{pH}$ буферних розчинів з препаратом.

При проведенні досліджень використовували наступне аналітичне обладнання: хроматографр Agilent
1100 3D LC System виробництва фрірми «Agilent Technologies» (США), забезпечений УФ-детектором, колонка Water Spherisorb CNRP розміром 250 мм $\mathrm{x}$ 4,6 мм, заповнена сорбентом з розміром часток 5 мкм для хроматографії; ваги лабораторні електронні Mettler Toledo AG 204 (Швейцарія), рН-метр-мілівольтметр pH-150 виробництва фрірми «ЗИП» (Білорусь), мірний посуд класу точності А. Буферні розчини $3 \mathrm{pH}$ 1,2, $\mathrm{pH}$ 4,5 і рН 6,8 готували відповідно до вимог ДФУ [6]. Для приготування буферних розчинів використовували реактиви фрармакопейної якості: кислоту хлористоводневу, натрію ацетат, кислоту оцтову льодяну, калію дигідрофроссрат, натрію гідроксид і натрію хлорид.

Результати й обговорення. На початку дослідження проаналізовано виконання загальних умов щодо можливості застосування процедури біовейвер до об'єктів дослідження і встановлено, що генеричні та референтні препарати знаходяться у твердій дозованій формі (тверді капсули) системної дії з негайним вивільненням для орального застосування з лікарською речовиною мельдоній в однаковій кількості 250 мг або 500 мг та однаковими допоміжними речовинами (табл. 1) і не мають вузького терапевтичного діапазону, тобто за всіма критеріями відповідають встановленим вимогам.

Подальші дослідження спрямовані на визначення для діючої речовини класу БСК. Для багатьох діючих речовин, як і для мельдонію, така інфоормація відсутня, що потребує проведення вивчення розчинності мельдонію та ступеня його проникнення.

Лікарська речовина мельдоній - це 3-(2,2,2-триметилгідразинію)пропіонат, дигідрат, яку на даний час описано у $[4,7]$. Згідно з нормативною документацією $[4,7]$, мельдоній належить до дуже легкорозчинних у воді речовин. Хімічна структура цього АФІ (рис. 1) містить частини (четвертинний амонієвий азот та карбоксильна група), які залежно від рН середовища несуть протилежні заряди, локалізовані на різних атомах. Наявність в хімічній структурі мельдонію

Таблиця 1. Порівняльна оцінка складу об'єктів дослідження

\begin{tabular}{|c|c|c|c|}
\hline \multicolumn{4}{|c|}{ Склад } \\
\hline \multicolumn{2}{|c|}{ рефрерентного препарату } & \multicolumn{2}{|c|}{ досліджуваного препарату } \\
\hline $\begin{array}{l}\text { 3-(2,2,2-триметилгідразинію) } \\
\text { пропіонат, дигідрат }\end{array}$ & $\begin{array}{l}250 \mathrm{Mr}, \\
500 \mathrm{Mr}\end{array}$ & $\begin{array}{l}\text { 3-(2,2,2-триметилгідразинію) } \\
\text { пропіонат, дигідрат }\end{array}$ & $\begin{array}{l}250 \mathrm{Mr}, \\
500 \mathrm{Mr}\end{array}$ \\
\hline \multicolumn{4}{|c|}{ Допоміжні речовини } \\
\hline \multicolumn{2}{|l|}{ Крохмаль картопляний } & \multicolumn{2}{|l|}{ Крохмаль картопляний } \\
\hline \multicolumn{2}{|l|}{ Кремнію діоксид колоїдний безводний } & \multicolumn{2}{|c|}{ Кремнію діоксид колоїдний безводний } \\
\hline Кальцію стеарат & & \multicolumn{2}{|c|}{ Кальцію стеарат } \\
\hline
\end{tabular}

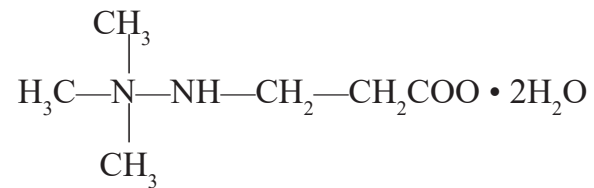

Рис. 1. Хімічна структура мельдонію дигідрату.

ISSN 2312-0967. Фармацевтичний часопис. 2016. № 3 
Фармакокінетика і фармакодинаміка Pharmacokinetics and Pharmacodynamics

груп подвійної природи визначає його розчинність і кислотно-основні властивості та дає можливість припустити, що дана сполука розчинна у рекомендованих середовищах розчинення у діапазоні рH 1,2-6,8.

Для підтвердження даного припущення та визначення розчинності діючої речовини було проведено визначення профілю $\mathrm{pH}$-залежної розчинності мельдонію відповідно до вимог [2, 3] в трьох середовищах розчинення із значенням рН 1,2, pH 4,5 і рН 6,8 при температурі $(37 \pm 1){ }^{\circ} \mathrm{C}$ методом струшування вищої разової дози АФІ до повного розчинення.

Згідно 3 результатами дослідження розчинності діючої речовини встановлено, що вища разова доза мельдонію повністю розчиняється в меншому об'ємі, ніж 250 мл кожного $з$ трьох буферних розчинів 3 досліджуваними значеннями $\mathrm{pH}$, тобто ця речовина належить до речовин із високою розчинністю.

Ступінь проникнення діючої речовини мельдонію дигідрату встановлено в ДУ «Інститут фрармакології та токсикології НАМН України» з використанням методики вимірювання коефіцієнта проникнення крізь моношар культури клітин Сасо-2. Згідно з отриманими результатами дослідження середнє значення коефріцієнта проникнення для субстанції мельдонію дигідрату склало $(1,29 \pm 0,12) \mathrm{E}-05$ см/с, що відповідає критерію «високий ступінь проникнення».

Таким чином, спираючись на отримані результати проведених досліджень субстанції (показники розчинності та ступеня проникнення), встановлено, що мельдонію дигідрат належить до I класу за БСК, тобто проявляє високу розчинність і високий ступінь проникнення.

Наступний етап досліджень полягав у вивченні кінетики вивільнення мельдонію з досліджуваних та рефрерентних Л3, що проведено відповідно до вимог $[2,3]$. Результати дослідження розчинення генеричних та референтних капсул мельдонію по 250 мг і 500 мг наведено у таблицях 2, 3. Приклади профілів розчинення досліджуваного та референтного препаратів в дозі 250 мг при рH 1,2, pH 4,5 і pH 6,8 наведено на рисунках 2-4. Подібні профрілі розчинення досліджуваного та ресрерентного ЛЗ отримані для дози 500 мг.

Як видно з даних таблиць 2, 3, вивільнення мельдонію з генеричних капсул по 250 мг та 500 мг та

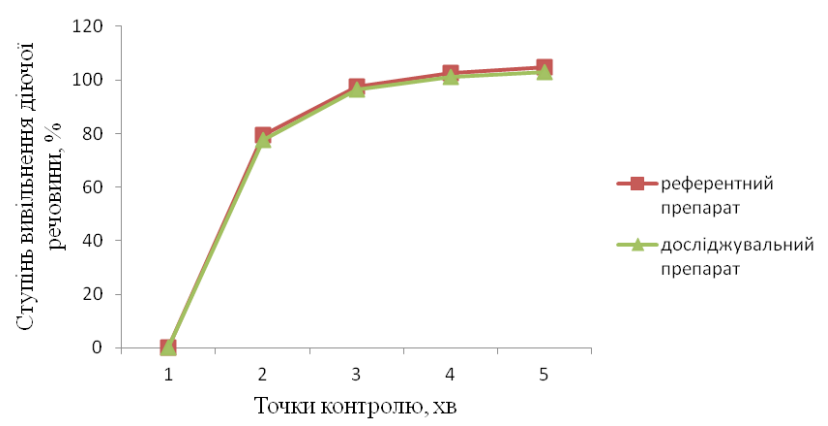

Рис. 2. Проорілі розчинення референтного та досліджуваного препаратів в дозі 250 мг у середовищі розчинення $3 \mathrm{pH} \mathrm{1,2.}$

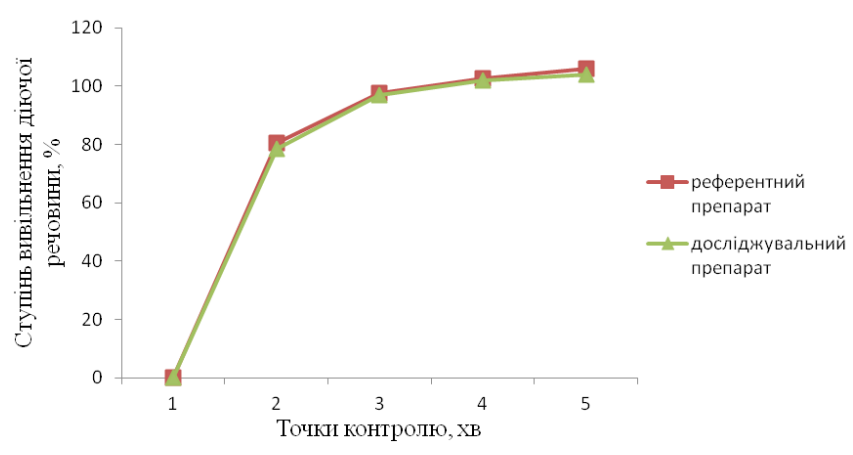

Рис. 3. Профрілі розчинення референтного та досліджуваного препаратів в дозі 250 мг у середовищі розчинення $3 \mathrm{pH} \mathrm{4,5.}$

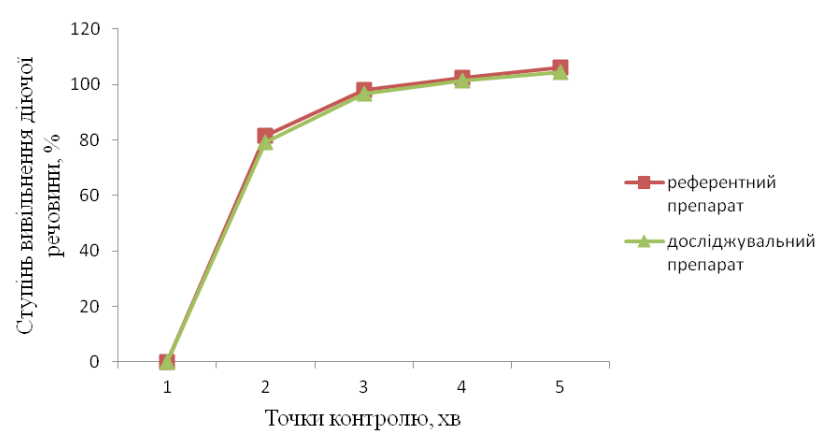

Рис. 4. Профрілі розчинення референтного та досліджуваного препаратів в дозі 250 мг у середовищі розчинення $3 \mathrm{pH} 6,8$.

Таблиця 2. Ступінь вивільнення мельдонію з капсул по 250 мг залежно від рH середовища

\begin{tabular}{|c|c|c|c|c|c|c|c|c|c|c|c|c|c|}
\hline \multirow{2}{*}{$\begin{array}{c}\text { Ступінь } \\
\text { вивільнення }\end{array}$} & \multirow{2}{*}{$\begin{array}{c}\text { рH } \\
\text { Час відбору } \\
\text { проби, хв }\end{array}$} & \multicolumn{4}{|c|}{1,2} & \multicolumn{4}{|c|}{4,5} & \multicolumn{4}{|c|}{6,8} \\
\hline & & 10 & 15 & 30 & 45 & 10 & 15 & 30 & 45 & 10 & 15 & 30 & 45 \\
\hline \multirow{2}{*}{$\begin{array}{c}\text { Середнє } \\
\text { значення, \% }\end{array}$} & $\begin{array}{l}\text { Pесрерентний } \\
\text { препарат }\end{array}$ & 79,6 & 97,6 & 102,6 & 104,8 & 80,4 & 97,6 & 102,7 & 105,8 & 81,4 & 98,1 & 102,3 & 106,1 \\
\hline & $\begin{array}{c}\text { Досліджуваний } \\
\text { препарат }\end{array}$ & 77,5 & 96,3 & 101,1 & 103,0 & 78,5 & 96,8 & 102,0 & 103,8 & 79,3 & 96,6 & 101,5 & 104,3 \\
\hline \multirow{2}{*}{ RSD, $\%$} & $\begin{array}{c}\text { Ресрерентний } \\
\text { препарат }\end{array}$ & 6,9 & 4,9 & 3,5 & 3,0 & 7,0 & 3,8 & 2,0 & 2,2 & 7,0 & 4,2 & 2,9 & 2,6 \\
\hline & $\begin{array}{c}\text { Досліджуваний } \\
\text { препарат }\end{array}$ & 7,0 & 5,3 & 3,1 & 2,5 & 8,2 & 4,5 & 2,5 & 2,1 & 7,4 & 4,7 & 3,0 & 2,4 \\
\hline
\end{tabular}

ISSN 2312-0967. Pharmaceutical review. 2016. № 3 
Фармакокінетика і фармакодинаміка Pharmacokinetics and Pharmacodynamics

Таблиця 3. Ступінь вивільнення мельдонію з капсул по 500 мг залежно від рН середовища

\begin{tabular}{|c|c|c|c|c|c|c|c|c|c|c|c|c|c|}
\hline \multirow{2}{*}{$\begin{array}{c}\text { Ступінь } \\
\text { вивільнення }\end{array}$} & \multirow{2}{*}{$\begin{array}{c}\text { рH } \\
\text { Час відбору } \\
\text { проби, хв }\end{array}$} & \multicolumn{4}{|c|}{1,2} & \multicolumn{4}{|c|}{4,5} & \multicolumn{4}{|c|}{6,8} \\
\hline & & 10 & 15 & 30 & 45 & 10 & 15 & 30 & 45 & 10 & 15 & 30 & 45 \\
\hline \multirow{2}{*}{$\begin{array}{c}\text { Середнє } \\
\text { значення, \% }\end{array}$} & $\begin{array}{c}\text { Ресрерентний } \\
\text { препарат }\end{array}$ & 80,6 & 97,8 & 102,4 & 104,1 & 81,3 & 98,0 & 102,6 & 105,1 & 82,0 & 98,1 & 102,9 & 105,0 \\
\hline & $\begin{array}{c}\text { Досліджуваний } \\
\text { препарат }\end{array}$ & 77,7 & 96,2 & 101,1 & 102,8 & 80,3 & 96,5 & 101,3 & 104,0 & 81,1 & 97,0 & 101,5 & 103,6 \\
\hline \multirow[t]{2}{*}{ RSD, \% } & $\begin{array}{c}\text { Рефрерентний } \\
\text { препарат }\end{array}$ & 7,4 & 4,8 & 3,5 & 3,3 & 7,2 & 5,6 & 3,3 & 3,3 & 6,7 & 5,7 & 2,7 & 2,9 \\
\hline & $\begin{array}{c}\text { Досліджуваний } \\
\text { препарат }\end{array}$ & 7,1 & 4,3 & 3,5 & 3,6 & 7,1 & 4,9 & 3,3 & 3,3 & 6,2 & 4,2 & 3,0 & 2,8 \\
\hline
\end{tabular}

референтних препаратів у всіх 3-х рекомендованих середовищах розчинення $3 \mathrm{pH} 1,2, \mathrm{pH} 4,5$ i pH 6,8 складає більше 85 \% від зазначеної на етикетці кількості діючої речовини за 15 хв. Це означає, що об'єкти дослідження належать до дуже швидкорозчинних Лз у всіх рекомендованих середовищах розчинення. Враховуючи вищевстановлені профрілі розчинення досліджуваних і референтних ЛЗ та достовірність результатів, на що вказують значення відносного стандартного відхилення (RSD) для генеричних і ресрерентних Л3 (див. табл. 2, 3), подібність досліджуваних капсул мельдонію може бути прийнята без математичного обчислення фрактора подібності.

Висновки. 1. Проведений комплекс досліджень щодо визначення біоеквівалентності між генеричними та референтними ЛЗ мельдонію, що включав аналіз виконання загальних умов щодо можливості застосування процедури біовейвер, вивчення розчинності і ступеня проникнення діючої речовини, визначення і порівняння профрілів розчинення генеричних та референтних препаратів.

2. За результатами дослідження встановлено:

- належність мельдонію до I класу за БСК;

- належність генеричних та референтних ЛЗ до дуже швидкорозчинних лз у всіх рекомендованих середовищах розчинення.

3. Подібність профілів розчинення свідчить про еквівалентність генеричних та референтних лікарських засобів мельдонію.

4. Отримані результати дозволили прийняти рішення щодо реєстрації генеричних ЛЗ за процедурою біовейвер без проведення досліджень біоеквівалентності in vivo.

\section{Список літератури}

1. Компендіум on-line. - [Електронний ресурс]. - Режим доступу: - http://compendium.com.ua/

2. СТ-Н МОЗУ 42-7.1:2014. Лікарські засоби. Дослідження біоеквівалентності / ДП «Державний експертний центр МО3 України», МОЗ України. - Введ. 2014.06.30. - К. : Міністерство охорони здоров'я України, 2014. - 59 с.

3. Про внесення змін до Порядку проведення експертизи реєстраційних матеріалів на лікарські засоби, що подаються на державну реєстрацію (перереєстрацію), а також експертизи матеріалів про внесення змін до реєстраційних матеріалів протягом дії реєстраційного посвідчення та затвердження Порядку перевірки матеріалів, доданих до зміни про державну реєстрацію окремих лікарських засобів, щодо їх обігу : наказ МОЗ України № 460 від 23.07.2015. - [Електронний ресурс].

- Режим доступу: - http:// zakon.rada.gov.ua/laws/show/ z1210-15

4. European Pharmacopoeia.- 8th ed. - Strasbourg: Council of Europe, 2013.- 3639 p.

5. Регистр лекарственных средств России ${ }^{\circledR}$. РлС ${ }^{\circledR}$. [Електронний ресурс]. - Режим доступу: - http://www. rlsnet.ru/

6. Державна Фармакопея України: в 3 т. / Державне підприємство «Український науковий фрармакопейний центр якості лікарських засобів». -2-е вид. - Х. : Державне підприємство «Український науковий фрармакопейний центр якості лікарських засобів», 2015. - Т. 1. - 1128 с.

7. Государственная фрармакопея Российской Федерации. - XII изд. - Ч. І. - Москва : «Издательство «Научный центр экспертизы средств медицинского применения», 2008. - 704 c.

ISSN 2312-0967. Фармацевтичний часопис. 2016. № 3 


\title{
КОМПЛЕКСНЫЕ ИССЛЕДОВАНИЯ ЭКВИВАЛЕНТНОСТИ IN VITRO КАПСУЛ МЕЛЬДОНИЯ
}

\author{
С. Ю. Висыч, А. В. Доровской, Е. Г. Фетисова, Л. Н. Андрюкова
}

Национальный фрармацевтический университет, Харьков

Резюме: в статье приведены результаты комплекса исследований биоэквивалентности генерическихи референтных лекарственных средств мельдония в форме твердых капсул по 250 мг и 500 мг по процедуре биовейвер. По результатам изучения растворимости и степени проницаемости установлен I класс по БСК для действующего вещества мельдоний. Определенно, что объекты исследования принадлежат к очень быстрорастворимым лекарственным средствам во всех рекомендованных средах растворения. Подобие просрилей растворения свидетельствует об эквивалентности генерических и референтных лекарственных средств мельдония.

Ключевые слова: мельдоний, капсулы, биофармацевтическая система классификации, биовейвер, исследование биоэквивалентности in vitro, растворимость, профили растворения.

\section{IN VITRO COMPLEX EQUIVALENCE STUDIES OF MELDONIUM CAPSULES}

\section{S. Yu. Visych, O. V. Dorovskyi, O. H. Fetisova, L. M. Andryukova}

National University of Pharmacy, Kharkiv

Summary: the results of complex bioequivalence studies of generic and reference drugs of Meldonium in form solid capsules of $250 \mathrm{mg}$ and $500 \mathrm{mg}$ by biowaiver procedure are presented in the article. Investigation of Meldonium solubility and degree of penetration studies found that Meldonium belongs to I class according to biopharmaceutical classification system. It was defined, that research objects belong to rapidly soluble drugs in all recommended dissolution medium. The similarity of dissolution profiles demonstrates the equivalence of generic and reference drugs of meldonium.

Key words: Meldonium, capsules, biopharmaceutical classification system, biowaiver, investigation of bioequivalence in vitro, solubility, dissolution profile. 